\title{
FAKTOR YANG MEMPENGARUHI PERILAKU KONSUMSI PRODUK HALAL PADA KALANGAN MAHASISWA MUSLIM
}

\author{
Nurul Huda \\ pakhuda@yahoo.com \\ Hulmansyah \\ Universitas YARSI \\ Nova Rini \\ Sekolah Tinggi Ilmu Ekonomi Muhammadiyah Jakarta
}

\begin{abstract}
The purpose of this study is to examine the factors of knowledge, attitude, subjective norms, behavioral control, and religious commitment to influence behavior through intentions for consumption of halal products. Based on the literature review, this research hypothesis states that knowledge, attitudes, subjective norms, behavioral control, and religious commitment affect the behavior through intention. This study uses survey data from questionnaires to 150 respondents. Hypothesis testing technique is done by using SEM analysis with Lisrel software. The results of data processing indicate that Knowledge, Attitudes, Subjective Norms, Behavior Control, and Religious Commitment have a significant influence on behavior through intention to consume halal products. Intensi variables have a significant influence on the consumption behavior of halal products with $t$ value of 7.14. Behavior Control and Religious Commitment have a greater influence on behavior through intention to consume halal products than other variables. Suggestions based on the results of research: first, need to consciously consume halal products by increasing one's religious commitment. Second, it needs to be enhanced the role of society both from internal and external in controlling one's behavior to consume halal product.
\end{abstract}

Key words: consumber behavior; intent; halal product

\begin{abstract}
ABSTRAK
Tujuan penelitian ini adalah menguji faktor pengetahuan, sikap, norma subyektif, kendali perilaku, dan komitmen beragama terhadap perilaku melalui intensi untuk konsumsi produk halal. Berdasarkan tinjauan literatur, hipotesis penelitian ini menyatakan bahwa pengetahuan, sikap, norma subyektif, kendali perilaku, dan komitmen beragama berpengaruh terhadap perilaku melalui intensi. Penelitian ini menggunakan data hasil survey dari penyebaran kuesioner kepada 150 responden. Teknik pengujian hipotesis dilakukan dengan menggunakan analisis SEM dengan software Lisrel. Hasil pengolahan data menunjukkan bahwa Variabel Pengetahuan, Sikap, Norma Subjektif, Kendali Perilaku, dan Komitmen Beragama memiliki pengaruh yang signifikan terhadap perilaku melalui intensi untuk mengkonsumsi produk halal. Variabel Intensi memiliki pengaruh yang signifikan terhadap perilaku konsumsi produk halal dengan nilai t sebesar 7,14. Variabel Kendali Perilaku dan Komitmen Beragama memiliki pengaruh yang lebih besar terhadap perilaku melalui intensi untuk mengkonsumsi produk halal daripada variabel lain. Saran berdasarkan hasil penelitian: pertama, perlu penyadaran mengkonsumsi produk halal dengan meningkatkan komitmen beragama seseorang. Kedua, perlu ditingkatkan peran masyarakat baik dari internal maupun eksternal dalam mengendalikan perilaku seseorang untuk mengkonsumsi produk halal.
\end{abstract}

Kata-kata kunci: perilaku konsumen, intensi, produk halal 


\section{PENDAHULUAN}

Segala jenis kegiatan manusia yaitu kegiatan berdagang maupun kegiatan konsumsi berhubungan dengan halal dan haram. Hubungan halal dan haram dalam kegiatan berdagang dilihat berdasarkan bersih dari unsur riba, Mayshir, Gharar, tadlis dan lain sebagainya. Dasar hukum mengenai kehalalan suatu hal terdapat dalam Al-Qur'an dan Hadits, yaitu Al Qur'an surat Al-Baqarah ayat 168.

"Hai sekalian manusia, makanlah yang halal lagi baik dari apa yang terdapat di bumi, dan janganlah kamu mengikuti langkah-langkah syaitan; Karena Sesungguhnya syaitan itu adalah musuh yang nyata bagimu". (Al Baqarah: 168)

Indonesia menempati posisi negara konsumen terbesar dari produk makanan halal dunia, yaitu sebesar US\$ 197 miliar dan diikuti Turki sebesar US\$ 100 miliar. Namun sayangnya Indonesia hanya menduduki peringkat ke-10 dalam industri dan pasar halal dunia, sedangkan Malaysia peringkat pertama. Berdasarkan sebuah report "State of the Global Economy: 2014-2105 Report" yang dirilis oleh Thomson Reuters bersama dengan Dubai Islamic Economy Development Center telah menempatkan Indonesia di peringkat 10 dari total 70 negara yang memiliki perhatian dan program dalam hal pengembangan industry halal tersebut. Laporan tersebut memberikan gambaran perbandingan global dalam hal antara lain profil masing-masing sector, seberapa besar pasarnya dan potensi yang bisa dikembangkan, tantangan-tantangan dalam pengembangannya, kesiapan landasan hukum dan peraturan serta seberapa besar dukungan pemerintah serta tingkat kesadaran masyarakatnya (Reuters, 2014).

Perilaku konsumen mengkonsumsi produk halal akan menjadi barometer permintaan (demand side) pada produk halal tersebut. Peningkatan permintaan suatu produk akan berpengaruh terhadap penawaran produk (supply side), sesuai dengan teori ekonomi. Hal ini menunjukkan bahwa pengetahuan tentang demand side sangat bermanfaat dan juga bisa menjadi prasyarat utama dalam melihat peluang usaha yang akan dikembangkan. Kajian tentang perilaku konsumen muslim Indonesia dalam mengkonsumsi produk halal akan memberikan dampak pada pertumbuhan ekonomi. Pertumbuhan ekonomi tersebut didorong dari peningkatan investasi pada penyedia produk halal.

Hasil penelitian yang telah dilakukan oleh Jusmaliani dan Nasution (2009) menunjukkan $80 \%$ responden menyatakan sangat setuju bahwa mengkonsumsi makanan halal adalah penting. Responden dalam penelitian Jusmaliani dan Nasution (2009) adalah Muslim Indonesia yang tinggal di Jakarta (87) dan Melbourne (73).

Hasil Riset Jusmaliani dan Nasution (2009) menyatakan mengkonsumsi makanan halal adalah penting, hanya saja masyarakat muslim kurang memperhatikan labelisasi produk halal. Penelitian ini merupakan bagian kecil dari penelitian prilaku konsumsi masyarakat khususnya Mahasiswa terhadap produk halal, faktor apa saja yang mendorong Mahasiswa untuk mengkonsumsi produk halal dengan pendekatan Teori Planned Behaviour yang dimodifikasi

Berdasarkan uraian latar belakang, maka pertanyaan penelitian dapat dirumuskan sebagai berikut. Pertama, Apakah faktor pengetahuan mempengaruhi perilaku melalui intensi untuk konsumsi produk halal?; Kedua, Apakah faktor sikap mempengaruhi perilaku melalui intensi untuk konsumsi produk halal?; Ketiga, Apakah faktor norma subyektif mempengaruhi perilaku melalui intensi untuk konsumsi produk halal?; Keempat, Apakah faktor kendali perilaku mempengaruhi perilaku melalui intensi untuk konsumsi produk halal?; dan Kelima, Apakah faktor komitmen beragama mempengaruhi perilaku melalui intensi untuk konsumsi produk halal?

\section{TINJAUAN TEORETIS \\ Esensi Produk Halal}

Istilah halal menurut Qardhawi adalah sebagai segala sesuatu yang boleh di- 
kerjakan, dan syariat membenarkan serta orang yang melakukannya tidak kena sanksi dari Allah WST (Khalek dan Ismail ,2015). Yusoff et al. (2014) memberikan definisi yang sama bahwa Halal ialah istilah bahasa Arab yang bermaksud dibenarkan

Halal, haram dan syubhat merupakan tiga kriteria dasar dalam menentukan suatu makanan boleh di makan atau dilarang untuk dikonsumsi. "Sesungguhnya yang halal itu jelas dan yang haram pun jelas. Dan di antara keduanya ada hal-hal yang samar atau tidak jelas". (HR. Bukhari).

Hadits yang diriwayatkan Bukhari tersebut menunjukkan penjelasan dari halal, haram dan syubhat. Halal merupakan sesuatu yang diperbolehkan untuk dikonsumsi. Haram merupakan sesuatu yang dilarang untuk di konsumsi. Syubhat adalah sesuatu kondisi yang berada diantara keduanya, bahwa terdapat dalil yang tidak jelas mengenai halal-haramnya suatu makanan. Syubhat juga bisa disebabkan adanya perbedaan pendapat diantara para ahli fiqih dalam menetapkan suatu makanan. Mengatasi masalah syubhat, Islam menekankan untuk mengambil sikap hatihati (wara'). Sehingga produk makanan atau kegiatan yang syubhat lebih baik dijauhi supaya tidak terjerumus kepada halhal yang haram.

Makanan halal banyak disediakan oleh Allah SWT daripada makanan yang haram. Surat Al Baqarah ayat 173 dan surat Al Maidah ayat 3 menjelaskan produk makanan halal dan haram. Allah mengharamkan bangkai, darah, daging babi, dan binatang (daging hewan) yang ketika disembelih disebut (nama) selain Allah. Selain menentukan produk makanan yang halal dan haram, Islam juga mengatur produk minuman. Minuman yang dilarang atau haram menurut Islam adalah minuman keras yang biasa disebut khamar. Penjelasan produk minuman tersebut terdapat dalam Al Qur'an surat Al Ma'idah ayat 90. Menurut Syafie dan Othman dalam Sutrisno (2013), makanan halal adalah dilihat dari proses pemotongan, penyimpanan, penyajian, pe- nyiapan, kesehatan dan kebersihan. Penjelasan Syafie dan Othman dalam Sutrisno (2013) tersebut menunjukkan bahwa selain makanan halal, juga diwajibkan mengkonsumsi makanan yang baik (Thoyib). Makanan yang baik (Thoyib) tersebut seperti makanan yang belum kadaluarsa, tidak mengandung pewarna pakaian, dsb. Mengkonsumsi produk halal merupakan kegiatan yang mutlaq dan tidak bisa ditawar-tawar lagi. Hal ini berdasarkan Surat Al-Maidah ayat 88: "Dan makanlah makanan yang halal lagi baik dari apa yang Allah Telah rezekikan kepadamu, dan bertakwalah kepada Allah yang kamu beriman kepada-Nya". (Al Maidah: 88)

Dalam penelitian ini produk halal bukan hanya dinyatakan halal secara syar'i namun juga telah mendapatkan sertifikasi halal dari MUI. Produk ini mudah dikenali dengan adanya label halal yang dikeluarkan oleh Majelis Ulama Indonesia (MUI) pada kemasannya. Produk halal yang akan dilihat mencakup makanan dan minuman yang dikemas yang dikelola oleh pabrik dan makanan dan minuman yang dihidangkan oleh restauran/rumah makan.

\section{Perilaku Konsumen Islam}

Aspek kultural, sosial, personal dan karakteristik psikologis dapat mempengaruhi perilaku konsumen. Dari keempat aspek tersebut, maka aspek kultural dianggap yang paling besar pengaruhnya terhadap keinginan dan perilaku seseorang.

Elemen kunci dari aspek kultural tersebut adalah agama, dan aspek kultural ini dapat mempengaruhi perilaku dan keputusan membeli (Abhimantra et al., 2013; Astogini et al., 2011; Aisyah, 2014; Mokhlis, 2009). Johnstone (1975) menyatakan bahwa:

"Religion is a system of beliefs and practices by which group of people interprets and responds to what they feel is supernatural and sacred". Pernyataan Johnstone ini dikutip dari Shafie dan Othman (2008). Pernyataan Johnstone tersebut menunjukan bahwa pada umumnya agama mengatur tentang apa-apa yang diperbolehkan dan apa yang dilarang untuk 
dilakukan, termasuk perilaku konsumsi (Shafie dan Othman, 2008).

Sistem bahwa agama mengatur segala hal diformalkan oleh lembaga agama. Sistem tersebut diajarkan pada setiap generasi. Efek dari proses tersebut, maka agama dapat mempengaruhi perilaku konsumen dan perilaku pada umumnya (Mokhlis, 2009; Mathras et al., 2016). Perilaku konsumen tersebut khususnya pada keputusan membeli bahan makanan dan kebiasaan makan (Bonne et al. 2007). Schiffman dan Kanuk (2009) juga yang menyatakan bahwa keputusan untuk membeli dipengaruhi oleh identitas agama mereka (Shafie dan Othman, 2008). Adanya pengaruh unsur agama dalam keputusn membeli konsumen, maka konsumen yang beragama Islam dalam mengambil keputusan untuk mengkonsumsi sesuatu tidak hanya memperhatikan dari segi kebutuhan dan biaya yang harus dikeluarkan tetapi yang paling penting adalah sejauhmana barang yang dikonsumsi akan memberikan maslahah (manfaat dan berkah) secara maksimum (Pusat Pengkajian dan Pengembangan Ekonomi Islam, 2008).

Ada tiga nilai dasar yang menjadi pondasi bagi perilaku konsumsi masyarakat muslim (Huda dalam Wigati, 2011):

1. Keyakinan akan adanya hari kiamat dan kehidupan akhirat, prinsip ini mengarahkan seorang konsumen untuk mengutamakan konsumsi untuk akhirat daripada dunia. Mengutamakan konsumsi untuk ibadah daripada konsumsi duniawi. Konsumsi untuk ibadah merupakan future consumption (karena terdapat balasan surga di akherat), sedangkan konsumsi duniawi adalah present consumption.

2. Konsep sukses dalam kehidupan seorang muslim diukur dengan moral agama Islam, dan bukan dengan jumlah kekayaan yang dimiliki. Semakin tinggi moralitas semakin tinggi pula kesuksesan yang dicapai. Kebajikan, kebenaran dan ketaqwaan kepada Allah merupakan kunci moralitas Islam.
Kebajikan dan kebenaran dapat dicapai dengan perilaku yang baik dan bermanfaat bagi kehidupan dan menjauhkan diri dari kejahatan.

3. Kedudukan harta merupakan anugrah Allah dan bukan sesuatu yang dengan sendirinya bersifat buruk (sehingga harus dijauhi secara berlebihan). Harta merupakan alat untuk mencapai tujuan hidup, jika diusahakan dan dimanfaatkan dengan benar (QS.2.265).

\section{Teori Planned Behaviour Modifikasi}

Model perilaku konsumen yang dikembangkan oleh Ajzen dan Fishbein disebut model Theory of Planned Behavior (TPB). Teori ini yang awalnya dinamai Theory of Reasoned Action (TRA), dikembangkan di tahun 1967. Pada tahun 1988, hal lain ditambahkan pada model reasoned action yang sudah ada tersebut dan kemudian dinamai Theory of Planned Behavior (TPB), untuk mengatasi kekurangan dan kekuatan yang ditemukan oleh Ajzen dan Fishbein melalui penelitian-penelitian mereka dengan menggunakan TRA. Berawal dari timbulnya kritik terhadap teori dan pengakuan sikap yang seringkali tidak tepat, yaitu tidak dapat memperkirakan perilaku yang akan timbul. Ajzen dalam Huda et al. (2012), menambahkan menurut kerangka teori reasoned action intensi merupakan kekuatan utama yang menjadi sumber motivasi seseorang untuk bertingkah laku tertentu. Semakin kuat intensi untuk melakukan tingkah laku tertentu, maka semakin besar kemungkinannya untuk melakukan tingkah laku tersebut.

Kerangka pemikiran teori ini dimaksudkan untuk mengatasi masalah control volisional yang belum lengkap dalam teori terdahulu. Inti dari teori planned behavior tetap berada pada faktor intensi perilaku namun determinan intensi tidak hanya dua (sikap terhadap perilaku yang bersangkutan dan norma-norma subjektif) melainkan tiga, dimana dengan diikutsertakannya aspek perceived behavioral control (PBC) (Huda et al., 2012). 


\section{Sikap}

Variabel Sikap merupakan penggambaran hasil evaluasi seseorang terhadap suatu entitas (objek maupun perbuatan), apakah dia suka atau tidak suka (Huda et al., 2012; Shook dan Bratianu, 2010; Monintja, 2015). Seseorang akan cenderung memiliki "niat" lebih untuk melakukan sesuatu jika kegiatan tersebut adalah hal yang disukainya. Ketika konsumen merasa senang atau suka membeli produk halal maka konsumen akan cenderung memiliki niat untuk membeli produk halal lagi di masa depan (Endah, 2014).

Fishbein dan Ajzen dalam Huda et al. (2012) mendefinisikan attitude sebagai suatu faktor predisposisi atau faktor yang ada dalam diri seseorang yang dipelajari untuk memberikan respon dengan cara yang konsisten, yaitu suka atau tidak suka pada penilaian terhadap suatu objek yang diberikan. Sikap/akhlak menurut Hamzah Hakim, (2012); Herlyana, (2012); Kamal dan Ghani, (2014); Ghani et al., (2014) ada 3 yaitu: Akhlak terhadap Allah, Akhlak terhadap diri sendiri dan Akhlak terhadap sesama manusia.

\section{Norma Subyektif/Niat}

Norma subjektif merupakan persepsi yang bersifat individual tehadap tekanan sosial untuk melakukan/tidak melakukan perilaku tertentu. Norma subjektif dapat ditentukan dan diukur sebagai suatu kumpulan keyakinan normatif mengenai kesetujuan/ketidaksetujuan acuan yang signifikan terhadap suatu perilaku (Refiana dalam Santoso dan Indarini, 2010). Norma subyektif/Niat memiliki 3 bagian yaitu: niat ibadah, niat ta'at dan niat qurban (Abidin, 2012).

\section{Kendali Perilaku}

Ajzen dalam Huda et al. (2012) menyatakan bahwa variabel persepsi kendali perilaku adalah sebagai seberapa jauh seseorang percaya atau merasa mampu untuk melakukan sesuatu. Variabel Kendali Perilaku ini ditentukan oleh keyakinan individu mengenai kekuatan faktor eksternal dan faktor internal untuk memfasilitasi perilaku. Seseorang mempersepsikan dirinya mampu maka akan semakin besar intensi seseorang untuk melakukan

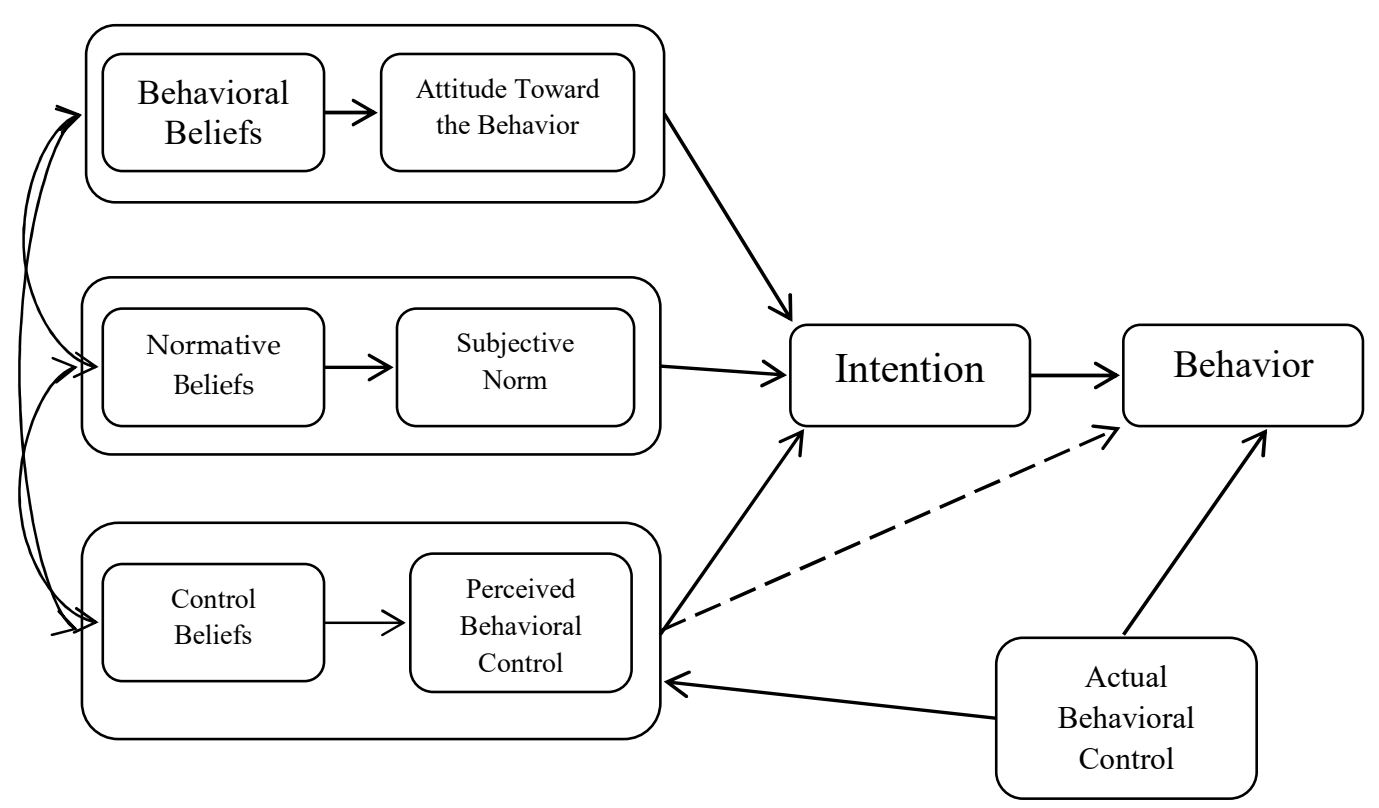

Gambar 1

Theory of Planned Behavior

Sumber: Ajzen, I dalam Huda et al. (2012) 
suatu perbuatan. Kondisi tersebut juga menunjukkan bahwa Jika seseorang mempersepsikan dirinya memiliki sumber daya untuk membeli kosmetik halal, maka niat untuk membeli kosmetik dengan label halal akan semakin besar.

Alam dan Nazura (2011) melakukan penelitian. Hasil penelitian Alam dan Nazura (2011) menunjukkan adanya pengaruh signifikan variabel persepsi kendali perilaku terhadap intensi pembelian produk halal. Kendali perilaku menurut Ghufron dan Risnawati (2010), ada 2 meliputi: faktor internal dan faktor eksternal.

\section{Komitmen Beragama}

Glock dan Strak merumuskan relegiusitas sebagai komitmen religius (yang berhubungan dengan agama atau keyakinan iman) yang dapat dilihat melalui aktivitas atau perilaku individu yang bersangkutan dengan agama atau keyakinan iman yang dianut. Religiusitas seringkali diidentikan dengan keberagamaan. Relegiusitas diartikan sebagai seberapa jauh pengetahuan. Seberapa kokoh kenyakinan. Seberapa pelaksanaan ibadah dan kaidah dan seberapa dalam penghayatan atas agama yang dianutnya. Inilah yang diwujudkan dalam perilaku sehari-hari. Komitmen beragama/ religiusitas, menurut Ancok dalam Putriani dan Shofawati (2015), memiliki 5 dimensi yaitu: dimensi keyakinan, dimensi peribadatan atau praktek agama, dimensi penghayatan, dimensi pengamalan, dan dimensi pengetahuan agama.

Konsumen Muslim yang memiliki religiositas tinggi umumnya cenderung memiliki kesadaran yang lebih tinggi untuk mengkonsumsi produk halal. Kelompok konsumen muslim juga cenderung memiliki ikatan sosial yang kuat karena frekuensi melakukan ibadah secara berjamaah akan semakin besar normative belief pada diri konsumen. Hasil penelitian sebelumnya mengenai produk halal dengan menggunakan model TPB menunjukkan bahwa sikap dan norma subjektif merupakan faktor yang signifikan mempengaruhi intensi seseorang untuk mengkonsumsi produk halal (Soesilowati, 2010; Lada et al., 2009; Bonne et al., 2010).

\section{Pengetahuan}

Pengetahuan menurut Notoatmodjo (2010) adalah hasil tahu manusia, ini terjadi setelah seseorang melakukan penginderaan terhadap sesuatu objek tertentu. Penginderaan terjadi melalui pancaindra manusia, yakni indra penglihatan, pendengaran, penciuman, rasa dan raba. Sebagaimana besar pengetahuan manusia diperoleh melalui mata dan telinga, karena dari pengalaman peneliti terbukti bahwa perilaku yang didasari oleh pengetahuan.

Engel, Blackwell dan Miniard dalam Marreiros dan Ness (2009) menyatakan bahwa, jenis pengetahuan terbagi dalam 3 (tiga) jenis:

1. Pengetahuan produk. Pengetahuan produk adalah kumpulan berbagai informasi mengenai produk. Pengetahuan ini meliputi kategori produk, merek, terminologi produk, atribut atau fitur produk, harga produk dan kepercayaan mengenai produk.

2. Pengetahuan pembelian. Pengetahuan pembelian meliputi berbagai informasi yang diproses oleh konsumen untuk memperoleh suatu produk. Pengetahuan produk terdiri atas pengetahuan dimana membeli produk dan kapan membeli produk.

3. Pengetahuan pemakaian. Suatu produk akan memberikan manfaat kepada konsumen jika produk tersebut telah digunakan atau dikonsumsi oleh konsumen. Agar produk tersebut bisa memberikan manfaat yang maksimal dan kepuasan yang tinggi kepada konsumen, maka konsumen harus bisa menggunakan atau mengkonsumsi produk tersebut dengan benar.

\section{Intensi Konsumen}

Menurut Ajzen dalam Huda et al. (2012), berdasarkan kerangka teori reasoned action intensi merupakan kekuatan utama 
yang menjadi sumber motivasi seseorang untuk bertingkah laku tertentu. Semakin kuat intensi untuk melakukan tingkah laku tertentu, maka semakin besar kemungkinannya untuk melakukan tingkah laku tersebut. Variabel intense masyarakat menurut Ajzen dalam Huda et al. (2012), meliputi 3 bagian yaitu: faktor pribadi (sikap, kepribadian, nilai, kondisi emosi, intelegensi), faktor sosial (usia, jenis kelamin, ras dan etnis, pendidikan, pendapatan, religi/ kepercayaan), dan Informasi (pengalaman, pengetahuan, media).

\section{Perilaku Konsumen}

Kotler dan Keller (2009) mendefinisikan perilaku konsumen adalah studi bagaimana tentang individu, kelompok, dan organisasi memilih, membeli, menggunakan, dan bagaimana barang, jasa, ide atau pengalaman untuk memuaskan kebutuhan dan keinginan mereka. Teori perilaku konsumen yang dibangun berdasarkan syariah Islam, memiliki perbedaan yang mendasar dengan teori konvensional. Perbedaan ini menyangkut nilai dasar yang menjadi pondasi teori, motif dan tujuan konsumsi, hingga teknik pilihan dan alokasi anggaran untuk berkonsumsi.

Perilaku konsumen menurut Islam, menurut Mannan dalam Arief (2012) ada 5 prinsip perilaku dalam Islam yaitu: prinsip keadilan, prinsip kebersihan, prinsip kesederhanaan, prinsip kemurahan hati dan prinsip moralitas. Penelitian ini membahas mengenai wakaf uang, maka dari 5 indikator perilaku konsumen menurut Islam, yang digunakan dalam penelitian ini adalah 3 indikator, yaitu : prinsip moralitas, prinsip kemurahan hati dan prinsip kesederhanaan.

\section{Penelitian Terdahulu}

Tahun 2014, Endah melakukan penelitian. Tujuan penelitian Endah (2014) adalah untuk menganalisis perilaku dan faktorfaktor yang mempengaruhi keputusan pembelian kosmetik berlabel halal oleh konsumen wanita di Indonesia. Endah (2014) mengasumsikan perilaku pembelian ter- bentuk dari proses kognisi dan dengan mengadopsi model Theory of Planned Behavior diketahui sikap, norma subjektif, dan persepsi kendali perilaku memiliki pengaruh terhadap niat konsumen untuk membeli kosmetik berlabel halal tersebut. Hasil penelitian Endah (2014) dapat diketahui pula faktor norma subjektif memiliki pengaruh yang paling besar terhadap niat pembelian dan secara signifikan norma subjektif juga memiliki pengaruh terhadap sikap konsumen akan kosmetik halal. Hasil penelitian Endah (2014) tersebut menunjukkan bahwa produsen dapat membuat strategi pemasaran yang lebih efektif yaitu dengan membentuk persepsi positif di lingkungan sosial konsumen. Variabel kualitas, keamanan, kesehatan dan layanan purna jual produk merupakan variabel lain yang digunakan konsumen untuk mengevaluasi produk, sementara atribut berupa harga dan distribusi akan menentukan apakah konsumen merasa mampu atau tidak untuk membeli kosmetik halal.

Penelitian-penelitian terdahulu memperlihatkan adanya hubungan positif antara tingkat religiositas seseorang dengan perilaku konsumsi (Borzooei dan Asgari, 2013; Salehudin dan Lutfhi, 2011; Soesilowati, 2010). Perilaku konsumen seseorang akan cenderung sesuai dengan aturan agama, jika konsumen tersebut memiliki religiositas yang tinggi. Seorang konsumen yang muslim, dia tidak akan mengkonsumsi produk yang mengandung zat haram seperti daging babi, darah, alkohol, hewan buas, hewan yang menijikkan, hewan yang disembelih tidak sesuai dengan syariah Islam, dan produk-produk yang syubhat. Tingkat kesadaran halal dan kehati-hatian mereka pun akan cenderung lebih tinggi.

Soesilowati (2010) melakukan penelitian mengenai perilaku konsumen yang juga seorang muslim tersebut. Hasil penelitian Soesilowati (2010) menunjukkan bahwa konsumen Muslim di Banten menempatkan "halal" sebagai kriteria utama dalam memilih makanan. Konsumen muslim di Banten dalam penelitian Soesilowati (2010) 
juga memiliki kesadaran yang rendah untuk memeriksa apakah ada jaminan halal (berupa logo halal dari LPPOM MUI) yang tercantum pada kemasan. Konsumen dalam penelitian Soesilowati (2010) menganggap jaminan halal tersebut bukan suatu hal yang krusial dan selama pedagang yang menjual produk tersebut beragama Islam maka produk tersebut sudah dianggap halal. Namun demikian, produsen tidak bisa serta merta mengabaikan label halal pada produk mengingat dengan akan disahkannya Rancangan Undang-Undang Jaminan Produk Halal pada tahun 2014 maka produk konsumsi non-haram (termasuk kosmetik) yang beredar di Indonesia wajib memiliki sertifikat halal. Tujuan utama logo halal pada berbagai produk adalah untuk melindungi konsumen Muslim (dari segi halal) dan juga konsumen non Muslim (dari segi thayyib), namun di sisi lain sertifikasi halal yang bersifat wajib ini dikhawatirkan akan memberatkan produsen kosmetik kecil karena untuk melakukan sertifikasi seringkali membutuhkan biaya yang tidak sedikit.

\section{METODE PENELITIAN}

\section{Populasi dan Sampel Penelitian}

Populasi dalam penelitian ini adalah mahasiswa muslim. Teknik pemilihan sampel menggunakan convenient sampling dan snowball sampling. Adapun wilayah pengambilan sampel adalah Perguruan Tinggi Islam di Wilayah Jakarta Timur dan Pusat dengan Pertimbangan wilayah tersebut yang banyak perguruan Tinggi Islam.

Penelitian ini memiliki tujuh variabel laten dan 22 indikator. Pengumpulan data untuk melihat hubungan variabel laten dilakukan dengan menggunakan kuesioner five-point Likert scale di mana (1) untuk pilihan "Sangat Tidak Setuju" hingga (5) "Sangat Setuju". Sementara untuk pertanyaan demografi menggunakan pilihan berganda. Adapun indikator pertanyaan atau variabel pengukuran dalam penelitian ini diadaptasi dari beberapa sumber. Menurut Bentler dan Chou dalam Zuhdi et al. (2016) jumlah sampel minimal yang dibutuhkan adalah jumlah item pertanyaan dikalikan dengan lima. Dengan demikian, jumlah responden yang dibutuhkan dalam penelitian ini minimal adalah 110 (22 pertanyaan $x$ 5) responden dan direncanakan akan disebar 150 Responden.

Data yang terkumpul kemudian dianalisis dengan menggunakan Structural Equation Modeling, dengan menggunakan LISREL for WINDOWS 8.51. SEM ini sebenarnya merupakan teknik regresi yang dilakukan secara simultan dan umum digunakan untuk mengukur variabel yang abstrak (tidak berwujud sehingga tidak dapat diamati langsung melalui panca indera).

\section{Jenis Data}

Metode pengumpulan data yang dilakukan untuk memperoleh dua jenis data yaitu data primer dan data sekunder. Pengumpulan data dilakukan untuk memperoleh informasi yang dibutuhkan dalam rangka mencapai tujuan penelitian.

Data Primer, dalam penelitian ini data primer diperoleh dari lapangan yang dilakukan dengan cara berikut ini: Kuesioner disebarkan kepada responden sebanyak 150 untuk mendapatkan data utama dalam penelitian ini, yakni sikap, norma subyektif, kendali perilaku, Pengetahuan dan komitmen beragama, untuk melakukan pembelian barang halal. Penyebaran kuesioner tersebut dilakukan pada sampel penelitian.

Data Sekunder, metode yang digunakan dalam pengumpulan data sekunder adalah arsipal atau dokumentasi, yakni dengan mempelajari dokumen yang berkaitan dengan penelitian ini.

\section{Metode Analisis Data}

Metode analisis data yang digunakan untuk pengujian hipotesis dalam penelitian ini adalah Structural Equation Modeling (SEM), menggunakan LISREL versi 8.5. SEM menjadi salah satu dari metode statistik multivariat yang paling populer yang menyediakan metodologi alternatif untuk pengujian teori terhadap data nonekspe- 
rimen dan juga menjadi alat yang sangat efektif dalam eksplorasi data (Bentler, 2010). SEM merupakan pengembangan dari beberapa teknik analisis statistik multivariate, khususnya analisis regresi ganda/path analysis dan analisis faktor sehingga cocok digunakan pada kajian mengenai hubungan antara konstruk laten (unobserverd) dalam model yang kompleks dengan melibatkan variabel inter- vening/variabel antara.

Keunggulan utama SEM adalah kemampuannya untuk mengestimasi para meter dalam model jalur sementara mengoreksi pengaruh bias dari kesalahan pengukuran yang random. Tidak seperti prosedur analisis multivariat tradisional (seperti analisis regresi atau path analysis) yang tidak mampu mengestimasi atau mengoreksi kesalahan pengukuran, SEM secara eksplisit memberikan estimasi terhadap varian kesalahan tersebut.

Analisis regresi atau path analysis mengasumsikan bahwa variabel independen benar-benar bebas dari kesalahan. Penggunaan kedua metode tersebut ketika terdapat kesalahan dalam variabel independen yang berarti mengabaikan kesalahan, akan menghasilkan ketidakakuratan yang serius terhadap hasil estimasi, lebihlebih jika kesalahan sangat besar. Masalah seperti ini dapat dihindari ketika meng- gunakan SEM (Byrne dalam Ghozali dan Fuad, 2008).

\section{ANALISIS DAN PEMBAHASAN \\ Deskripsi Statistik Data Penelitian}

Deskripsi statistik data hasil penelitian disajikan dengan maksud memberikan gambaran umum mengenai distribusi data yang merupakan hasil pengolahan dari tabulasi kuesioner atau data mentah (raw score) dengan menggunakan teknik statistik deskriptif yang bertujuan untuk memberikan gambaran umum mengenai distribusi data yang disajikan dalam bentuk distribusi rata-rata (mean) dan standar deviasi. Dengan tampilan ini, dapat diperoleh gambaran menyeluruh dari tiap variabel yang diteliti untuk menarik kesimpulan.

Penelitian ini mengukur tujuh variabel, yaitu perilaku $(\mathrm{Y})$, intensi $(\mathrm{Z})$, komitmen beragama $\left(X_{5}\right)$, kendali perilaku $\left(X_{4}\right)$, norma subejektif $\left(X_{3}\right)$, sikap $\left(X_{2}\right)$, dan pengetahuan $\left(X_{1}\right)$ yang dilakukan pada 148 orang responden. Setiap variabel diukur secara terpisah melalui intrumen penelitian yang berupa kuesioner berdasarkan metode skala likert dan data ordinal.

Data statistik deskriptif setiap variabel secara berurutan berdasarkan persepsi responden secara keseluruhan akan disajikan sebagai berikut:

Tabel 1

Statistik Deskriptif Variabel Penelitian Pengetahuan

\begin{tabular}{lcc}
\hline \multicolumn{1}{c}{ Variabel } & Mean & $\begin{array}{c}\text { Std. } \\
\text { Deviation }\end{array}$ \\
\hline $\begin{array}{l}\text { Pengetahuan } \\
\begin{array}{l}\text { Responden mengetahui adanya produk halal } \\
\text { tersertifikasi Majelis Ulama Indonesia (MUI) }\end{array}\end{array}$ & 4,44 & 0,662 \\
$\begin{array}{l}\text { Responden mengetahui cara pembelian produk halal } \\
\text { tersertifikasi Majelis Ulama Indonesia (MUI) } \\
\begin{array}{l}\text { Responden mengetahui manfaat pembelian produk } \\
\text { halal tersertifikasi Majelis Ulama Indonesia (MUI) }\end{array}\end{array}$ & 3,99 & 0,804 \\
\hline
\end{tabular}

Sumber : kuesioner, data diolah 
Tabel 2

Statistik Deskriptif Variabel Penelitian Sikap

\begin{tabular}{|c|c|c|}
\hline Variabel & Mean & $\begin{array}{c}\text { Std. } \\
\text { deviation }\end{array}$ \\
\hline $\begin{array}{l}\text { Sikap } \\
\text { Responden berkeinginan membeli produk halal } \\
\text { tersertifikasi Majelis Ulama Indonesia (MUI) sebagai } \\
\text { bagian pelaksanaan muamalah }\end{array}$ & 4,43 & 0,661 \\
\hline $\begin{array}{l}\text { Responden berkeinginan membeli produk halal } \\
\text { tersertifikasi Majelis Ulama Indonesia (MUI) untuk } \\
\text { menambah amal kebaikan }\end{array}$ & 4,38 & 0,695 \\
\hline $\begin{array}{l}\text { Responden menyadari pembelian produk halal } \\
\text { tersertifikasi Majelis Ulama Indonesia (MUI) bagian } \\
\text { dari menolong orang lain }\end{array}$ & 4,29 & 0,767 \\
\hline
\end{tabular}

Tabel 3

Statistik Deskriptif Variabel Penelitian Norma Subjektif/Niat

\begin{tabular}{lcc}
\hline \hline \multicolumn{1}{c}{ Variabel } & Mean & $\begin{array}{c}\text { Std. } \\
\text { deviation }\end{array}$ \\
\hline $\begin{array}{l}\text { Norma Subjektif/Niat } \\
\text { Responden berkeinginan menggunakan produk halal } \\
\text { tersertifikasi Majelis Ulama Indonesia (MUI) karena } \\
\text { sesuai tuntunan syariah (hukum Islam) }\end{array}$ & 4,58 & 0,628 \\
$\begin{array}{l}\text { Responden berkeinginan menggunakan produk halal } \\
\text { tersertifikasi Majelis Ulama Indonesia (MUI) karena }\end{array}$ & 4,51 & 0,633 \\
$\begin{array}{l}\text { MUI lembaga yang terpercaya untuk Menetapkan } \\
\text { Produk Halal }\end{array}$ & \\
$\begin{array}{l}\text { Responden menggunakan produk halal tersertifikasi } \\
\text { Majelis Ulama Indonesia (MUI) karena saya ingin } \\
\text { mendapatkan keridho'an Rizki yang saya terima dari } \\
\text { Allah }\end{array}$ & & \\
\hline $\begin{array}{l}\text { Sumber: kuesioner, data diolah } \\
\end{array}$ & & \\
\end{tabular}

Tabel 4

Statistik Deskriptif Variabel Penelitian Kendali Perilaku

\begin{tabular}{lcc}
\hline \hline \multicolumn{1}{c}{ Variabel } & Mean & $\begin{array}{c}\text { Std. } \\
\text { Deviation }\end{array}$ \\
\hline $\begin{array}{l}\text { Kendali Perilaku } \\
\text { Responden berkeinginan menggunakan produk halal } \\
\text { tersertifikasi Majelis Ulama Indonesia (MUI) karena } \\
\text { mengetahui manfaatnya }\end{array}$ & 4,36 & 0,640 \\
$\begin{array}{l}\text { Responden berkeinginan menggunakan produk halal } \\
\text { tersertifikasi Majelis Ulama Indonesia (MUI) karena } \\
\text { nasehat dari orang tua, teman, maupun ustadz } \\
\text { (guru/dosen) }\end{array}$ & & 0,918 \\
\hline Sumber: kuesioner, data diolah & &
\end{tabular}


Tabel 5

Statistik Deskriptif Variabel Penelitian Komitmen Beragama

\begin{tabular}{lcc}
\hline \hline \multicolumn{1}{c}{ Variabel } & Mean & $\begin{array}{c}\text { Std. } \\
\text { Deviation }\end{array}$ \\
\hline $\begin{array}{l}\text { Komitmen Beragama } \\
\text { Responden sangat meyakini menggunakan produk } \\
\text { halal tersertifikasi Majelis Ulama Indonesia (MUI) } \\
\text { akan memberikan keselamatan di dunia dan akhirat }\end{array}$ & 4,41 & 0,718 \\
$\begin{array}{l}\text { Responden sangat meyakini menggunakan produk } \\
\text { halal tersertifikasi Majelis Ulama Indonesia (MUI) } \\
\text { bagian dari peningkatan keberagamaam }\end{array}$ & 4,19 & 0,677 \\
$\begin{array}{l}\text { Responden sangat meyakini menggunakan produk } \\
\text { halal tersertifikasi Majelis Ulama Indonesia (MUI) } \\
\text { akan menambah ketenangan hidup }\end{array}$ & 4,20 & 0,746 \\
$\begin{array}{l}\text { Responden sangat meyakini menggunakan produk } \\
\text { halal tersertifikasi Majelis Ulama Indonesia (MUI) } \\
\text { menambah kesempurnaan hidup kita di dunia }\end{array}$ & 4,15 & 0,744 \\
$\begin{array}{l}\text { Responden sangat meyakini menggunakan produk } \\
\text { halal tersertifikasi Majelis Ulama Indonesia (MUI) } \\
\text { bagian dari aplikasi pengetahuan agama yang saya } \\
\text { peroleh dari buku maupun dari Ustadz }\end{array}$ & 4,23 & 0,701 \\
\hline $\begin{array}{l}\text { Sumber: kuesioner, data diolah } \\
\end{array}$ & & \\
\end{tabular}

Tabel 6

Statistik Deskriptif Variabel Penelitian Intensi

\begin{tabular}{lcc}
\hline \hline \multicolumn{1}{c}{ Variabel } & Mean & $\begin{array}{c}\text { Std. } \\
\text { Deviation }\end{array}$ \\
\hline $\begin{array}{l}\text { Intensi } \\
\begin{array}{l}\text { Responden akan menggunakan produk halal } \\
\text { tersertifikasi Majelis Ulama Indonesia (MUI) dalam } \\
\text { rangka ketaatan pada Allah }\end{array}\end{array}$ & 4,48 & 0,633 \\
$\begin{array}{l}\text { Responden akan menggunakan produk halal } \\
\text { tersertifikasi Majelis Ulama Indonesia (MUI) karena } \\
\text { saya mampu untuk melakukannya }\end{array}$ & 4,30 & 0,675 \\
$\begin{array}{l}\text { Responden akan menggunakan produk halal } \\
\text { tersertifikasi Majelis Ulama Indonesia (MUI) karena } \\
\text { akan meningkatkan kesejahteraan masyarakat }\end{array}$ & 4,14 & 0,756 \\
\hline $\begin{array}{l}\text { Sumber : kuesioner, data diolah } \\
\end{array}$ & & \\
\hline
\end{tabular}

Tabel 7

Statistik Deskriptif Variabel Penelitian Perilaku

\begin{tabular}{ccc}
\hline Variabel & Mean & $\begin{array}{c}\text { Std. } \\
\text { Deviation }\end{array}$ \\
\hline
\end{tabular}

\section{Perilaku}

Responden akan menggunakan produk produk halal 4,42 0,660 tersertifikasi Majelis Ulama Indonesia (MUI) karena produk tersebut sudah sesuai dengan fatwa yang 
dikeluarkan oleh MUI dan membuat hidup saya menjadi lebih tenang

Responden akan menggunakan produk produk halal

0,680

tersertifikasi Majelis Ulama Indonesia (MUI) karena produk tersebut memberi manfaat yang besar bagi masyarakat umum

Responden akan menggunakan produk produk halal tersertifikasi Majelis Ulama Indonesia (MUI) karena prosesnya yang sederhana

Sumber : kuesioner, data diolah

Hasil penelitian pada tabel 1 menunjukkan bahwa standar deviation dari variabel Pengetahuan adalah dapat diterima, dengan nilai standar deviation tidak lebih dari 3. Pada variabel Pengetahuan dari indikator Pengetahuan Produk yang terwakili dari pernyataan "Responden Mengetahui Adanya Produk Halal Tersertifikasi Majelis Ulama Indonesia (MUI)", memiliki rata-rata skor sebesar 4,44. Nilai rata-rata skor tersebut menunjukkan bahwa responden dalam penelitian ini memiliki pengetahuan yang tinggi berkaitan dengan pengetahuan produk halal. Indikator Pengetahuan Pemakaian yang diwakili oleh pernyataan "Responden mengetahui manfaat pembelian produk halal tersertifikasi Majelis Ulama Indonesia (MUI)", memiliki rata-rata skor juga besar yaitu sebesar 4,50, bahkan merupakan rata-rata skor tertinggi dalam variabel Pengetahuan. Hasil ini menunjukkan bahwa responden dalam penelitian ini memiliki tingkat Pengetahuan yang tinggi untuk pengetahuan pemakaian produk halal. Indikator Pengetahuan Pembelian yang diwakili dengan pernyataan "Responden mengetahui cara pembelian produk halal tersertifikasi Majelis Ulama Indonesia (MUI)", memiliki rata-rata skor sebesar 3,99.

Hasil penelitian ini juga menunjukkan bahwa responden dalam penelitian ini memiliki tingkat pengetahuan yang cukup tinggi mengenai pengetahuan pembelian produk halal. Ketiga ítem tersebut di atas memiliki nilai rata-rata skor diatas 3,00. Deskripsi persepsi responden dalam penelitian ini mengenai tingkat Pengetahuan responden pada produk halal menunjukkan rata-rata skor yang besar atau nilai yang besar. Hasil rata-rata skor yang diatas 3,00 menunjukkan bahwa tingkat pengetahuan responden mengenai produk halal mulai dari pengetahuan produk, cara pembelian dan pemakaian produk halal adalah tinggi atau besar.

Item pernyataan pada variabel Sikap yang memiliki nilai rata-rata skor tertinggi adalah sebesar 4,43. Nilai rata-rata skor tertinggi tersebut adalah untuk indikator Akhlak terhadap Allah. Indikator Akhlak terhadap Allah diwakili dengan pernyataan "Responden berkeinginan membeli produk halal tersertifikasi Majelis Ulama Indonesia (MUI) sebagai bagian pelaksanaan muamalah". Nilai rata-rata skor tertinggi kedua adalah sebesar 4,38. Nilai rata-rata skor tersebut untuk indikator Akhlak terhadap diri sendiri yang diwakili dengan pernyataan "Responden berkeinginan membeli produk halal tersertifikasi Majelis Ulama Indonesia (MUI) untuk menambah amal kebaikan". Indikator Akhlak terhadap sesama manusia yang diwakili dengan pernyataan "Responden menyadari pembelian produk halal tersertifikasi Majelis Ulama Indonesia (MUI) bagian dari menolong orang lain", memiliki rata-rata skor sebesar 4,29. Hasil deskripsi jawaban responden mengenai variabel Sikap, menunjukkan semua indikator memiliki rata-rata skor di atas 4,00. Nilai rata-rata skor diatas 4,00, menunjukkan bahwa Sikap yang dimiliki oleh responden dalam penelitian ini adalah sikap yang memiliki akhlak terhadap Allah, akhlak terhadap diri sendiri, dan akhlak terhadap sesame manusia yang tinggi. 
Tabel 3 di atas menunjukkan rata-rata nilai skor untuk variabel Norma Subjektif/Niat untuk semua indikator adalah diatas skor 4. Indikator dari variabel Norma Subjektif/Niat yang memiliki nilai rata-rata skor tertinggi dibandingkan indikatorindikator yang lain adalah indikator Niat Ibadah. Indikator Niat Ibadah memiliki rata-rata skor sebesar 4,58 diwakili dengan pernyataan "Responden berkeinginan menggunakan produk halal tersertifikasi Majelis Ulama Indonesia (MUI) karena sesuai tuntunan syariah (hukum Islam)".

Niat Qurban yang merupakan indikator ketiga dalam variabel Norma Subjektif/Niat juga memiliki nilai rata-rata skor yang tinggi yaitu sebesar 4,57. Indikator Niat Qurban diwakili dengan pernyataan "Responden menggunakan produk halal tersertifikasi Majelis Ulama Indonesia (MUI) karena saya ingin mendapatkan keridho'an Rizki yang saya terima dari Allah". Indikator Niat Ta' at yang merupakan indi- kator kedua dari variabel Norma Subjektif/ Niat juga memiliki nilai rata-rata skor yang tinggi dibandingkan dengan indikatorindikator lainnya. Indikator Niat Ta'at ini memiliki nilai rata-rata skor sebesar 4,51, hanya memiliki selisih sedikit dengan ratarata skor indikator lainnya. Indikator Niat Ta'at diwakili dengan pernyataan "Responden berkeinginan menggunakan produk halal tersertifikasi Majelis Ulama Indonesia (MUI) karena MUI lembaga yang terpercaya untuk Menetapkan Produk Halal".

Deskripsi data dari variable Norma Subjektf/Niat ini menunjukkan bahwa Norma Subjektif/Niat responden dalam menilai produk halal sudah besar. Hasil penelitian pada tabel 4 menunjukkan bahwa standar deviation dari variabel kendali perilaku pada responden adalah dapat diterima, dengan nilai standar deviation tidak lebih dari 3. Kedua indikator dari variabel Kendali Perilaku memiliki nilai rata-rata skor diatas 4. Hasil ini menunjukkan bahwa kendali perilaku yang dialami responden sangat tinggi. Indikator untuk mengukur kendali perilaku tersebut adalah faktor internal dan faktor eksternal. Faktor internal diwakili dengan pernyataan "Responden berkeinginan menggunakan produk halal tersertifikasi Majelis Ulama Indonesia (MUI) karena mengetahui manfaatnya". Indikator faktor eksternal diwakili dengan pernyataan "Responden berkeinginan menggunakan produk halal tersertifikasi Majelis Ulama Indonesia (MUI) karena nasehat dari orang tua, teman, maupun ustadz (guru/dosen)".

Deskripsi persepsi responden mengenai variabel komitmen beragama terlihat pada tabel 5 diatas. Hasil analisa data responden, dapat diketahui bahwa semua indikator variabel Komitmen Beragama memiliki nilai rata-rata skor diatas skor 4,00. Nilai rata-rata skor di atas 4,00 menunjukkan bahwa persepsi responden mengenai variabel komitmen beragama sangat tinggi. Hasil ini juga bisa menyimpulkan bahwa responden memiliki komitmen beragama yang tinggi.

Tabel 6 menunjukkan seberapa besar intensi responden dalam menggunakan produk halal. Ketiga indikator untuk mengukur variabel Intensi dalam penelitian ini menunjukkan nilai rata-rata skor diatas nilai skor 4,00. Nilai rata-rata skor diatas nilai skor 4,00 menunjukkan bahwa intensi responden dalam menggunakan produk halal sangat besar.

Variabel Perilaku dalam penelitian ini diukur dengan tiga indikator. Hasil penyebaran kuesioner dan perhitungan nilai rata-rata skor dan standar deviasi ditunjukkan pada tabel 7 diatas. Deskripsi data penelitian Perilaku menunjukkan bahwa ketiga indikator dalam mengukur Variabel Perilaku memiliki nilai rata-rata skor diatas nilai skor 4,00.

Hasil ini menunjukkan bahwa perilaku muslim dalam menggunakan produk halal cenderung akan menggunakan produk halal tersebut.

\section{Analisis SEM \\ Tahap Estimasi}

Setelah mengetahui bahwa identifikasi dari model adalah overidentified, maka 
tahap berikutnya adalah melakukan estimasi untuk memperoleh nilai parameterparameter yang ada di dalam model. Pada LISREL terdapat tujuh metode yang dapat digunakan untuk mengestimasi parameter dari suatu model, yaitu: Instrumental Variables (IV), Two Stage Least Square (TSLS), Unweighted Least Square (ULS), Generalized Least Square (GLS), Generally Weighted Least Square (GWLS), Diagonally Weighted Least Square (DWLS), dan Maximum Likelihood $(M L)$. Namun yang sering digunakan ada 3 metode yaitu Maximum Likelihood (ML), Robust Maximum Likelihood/Generalized Least Square, dan Weighted Least Square (WLS). (Ghozali dan Fuad, 2008).

Pada penelitian ini metode estimasi yang digunakan adalah Maximum Likelihood $(M L)$. Hal ini sesuai dengan syarat untuk menggunakan metode tersebut yaitu jumlah data yang digunakan antara 100 sampai 200. Metode estimasi yang paling popular digunakan pada penelitian SEM, dan secara default digunakan oleh LISREL adalah Maximum Likelihood. Maximum Likelihood akan menghasilkan parameter yang valid, efisien dan reliable apabila data yang digunakanadalah multivariate normality (normalitas multivariate) dan akan robust (tidak terpengaruh/kuat) terhadap penyimpangan multivariate normality yang sedang (moderate). Tetapi estimasi pada ML akan bias apabila pelanggaran terhadap multivariate normality sangat besar. Maximum Likelihood memiliki hasil yang cukup valid dengan besaran sampel minimal 50, tetapi menurut Hair dalam Ghozali dan Fuad (2008) ukuran sampel sebesar itu tidak dianjurkan.

Ukuran sampel yang disarankan untuk penggunaan estimasi Maximum Likelihood adalah sebesar 100-200. Kelemahan dari metode ML ini adalah ML akan menjadi "sangat sensitif" dan menghasilkan indeks goodness of fit yang buruk apabila data yang digunakan adalah besar (400-500). Ukuran sampel dalam penelitian ini adalah sebesar 148 sesuai dengan yang disyaratkan oleh metode estimasi Maximum Likelihood. Syarat yang harus terpenuhi untuk metode estimasi Maximum Likelihood selain memiliki ukuran sampel 100-200, data yang digunakan juga harus multivariate normality (normalitas multivariate). Jika nilai $\mathrm{z}$, baik zkurtosis dan/atau zskewness adalah signifikan (pvalue $<0,05)$, maka dapat dikatakan bahwa distribusi data adalah tidak normal. Sebaliknya, jika nilai $\mathrm{p}$-value $>0,05$, maka distribusi data adalah normal.

Menurut Curran dalam Ghozali dan Fuad (2008) apabila nilai skewness kurang dari 2 dan nilai kurtosis kurang dari 7, maka data adalah normal. Sedangkan jika nilai skewness berkisar antara 2 sampai 3 dan nilai kurtosis berkisar antara 7 sampai 21 maka distribusi data termasuk dalam moderately non normal. Distribusi data termasuk dalam kategori sangat tidak normal (extremely non normal) apabila memiliki nilai skewness lebih besar daripada 3 dan nilai kurtosis lebih besar daripada 21.

Tabel 8 berikut menunjukkan distribusi normal pada data dalam penelitian ini. Berdasarkan tabel 8 dapat diketahui bahwa nilai p-value untuk zskewness kebanyakan kurang dari 0,05 , delapan indikator yang memiliki $p$-value zskewness lebih dari dari 0,05 . Sementara nilai $p$-value $<0,05$ untuk nilai zkurtosis adalah variabel $\mathrm{X} 23, \mathrm{X} 41, \mathrm{Z1}$ dan Z3, karena data yang tidak berdistribusi normal tidak terlalu signifikan, sehingga data dalam penelitian ini cenderung memiliki distribusi normal. Sehingga metode estimasi yang digunakan adalah Maximum Likelihood (ML).

\section{Analisis Model Persamaan Struktural Estimasi Parameter}

Data-data berupa skor dianalisa menggunakan software LISREL. Hasil analisa data memunculkan sebuah diagram jalur dengan nilai estimasi parameter terstandarisasi untuk model perilaku yang dihipotesiskan. 
Tabel 8

Uji Normalitas

\begin{tabular}{ccccccc}
\hline \hline & \multicolumn{2}{c}{ Skewness } & \multicolumn{2}{c}{ Kurtosis } & \multicolumn{2}{c}{ Skewness and Kurtosis } \\
\hline Variable & Z-Score & P-Value & Z-Score & P-Value & Chi-Square & P-Value \\
\hline X11 & -2.954 & 0.003 & -1.439 & 0.150 & 10.794 & 0.005 \\
X12 & -1.274 & 0.203 & 0.342 & 0.733 & 1.739 & 0.419 \\
X13 & -3.546 & 0.000 & -1.104 & 0.269 & 13.796 & 0.001 \\
X21 & -2.875 & 0.004 & -1.455 & 0.146 & 10.383 & 0.006 \\
X22 & -2.976 & 0.003 & -1.894 & 0.058 & 12.444 & 0.002 \\
X23 & -2.711 & 0.007 & -2.368 & 0.018 & 12.955 & 0.002 \\
X31 & -4.290 & 0.000 & -0.309 & 0.758 & 18.502 & 0.000 \\
X32 & -3.103 & 0.002 & -1.732 & 0.083 & 12.629 & 0.002 \\
X33 & -4.228 & 0.000 & -0.294 & 0.768 & 17.964 & 0.000 \\
X41 & -2.161 & 0.031 & -3.247 & 0.001 & 15.213 & 0.000 \\
X42 & -1.791 & 0.073 & -1.392 & 0.164 & 5.146 & 0.076 \\
X51 & -3.394 & 0.001 & -1.869 & 0.062 & 15.011 & 0.001 \\
X52 & -1.411 & 0.158 & -0.386 & 0.699 & 2.141 & 0.343 \\
X53 & -1.994 & 0.046 & -1.664 & 0.096 & 6.746 & 0.034 \\
X54 & -1.695 & 0.090 & -1.199 & 0.231 & 4.311 & 0.116 \\
X55 & -1.858 & 0.063 & -1.298 & 0.194 & 5.137 & 0.077 \\
Z1 & -3.274 & 0.001 & -2.730 & 0.006 & 18.173 & 0.000 \\
Z2 & -2.052 & 0.040 & -1.182 & 0.237 & 5.609 & 0.061 \\
Z3 & -1.661 & 0.097 & -2.165 & 0.030 & 7.446 & 0.024 \\
Y1 & -2.992 & 0.003 & -1.557 & 0.119 & 11.375 & 0.003 \\
Y2 & -2.047 & 0.041 & -1.680 & 0.093 & 7.013 & 0.030 \\
Y3 & -1.320 & 0.187 & -0.861 & 0.389 & 2.484 & 0.289 \\
\hline
\end{tabular}

Sumber : Hasil pengolahan data dengan LISREL 8.5

Uji Kecocokan Model Keseluruhan

Untuk melihat apakah model sesuai dengan data yang ada, maka akan dilakukan pengujian kecocokan keseluruhan model dengan data.
Berikut ini adalah daftar criteria atau ukuran kecocokan model (GOF) yang digunakan untuk menguji model secara keseluruhan.

Tabel 9

Hasil Uji Kecocokan Model Keseluruhan

\begin{tabular}{|c|c|c|c|}
\hline Ukuran GOF & Target-Tingkat Kecocokan & Hasil Estimasi & $\begin{array}{c}\text { Tingkat } \\
\text { Kecocokan }\end{array}$ \\
\hline $\begin{array}{l}\text { Chi-Square } \\
\text { P-value } \\
\text { Normed Chi- } \\
\text { Square }\end{array}$ & $\begin{array}{l}\text { Semakin kecil semakin baik } \\
\text { p-value } \geq \text { a yang dipilih } \\
\text { Chi-Square/df, batas bawah : } \\
0.1 \\
\text { Batas atas : } 2.0 ; 3.0 ; 5.0\end{array}$ & $\begin{array}{l}X^{2}=383.97 ; d f=193 \\
p=0,00<0,05 \\
383.97 / 193=1.99\end{array}$ & Kurang fit \\
\hline $\begin{array}{l}\text { PGFI } \\
\text { RMSEA } \\
\text { P (close fit) }\end{array}$ & $\begin{array}{l}\text { PGFI }>0.6 \\
\text { RMSEA } \leq 0.08 \text { (good fit) } \\
\text { RMSEA }<0.05 \text { (close fit) }\end{array}$ & $\begin{array}{l}\text { PGFI }=0.62=0.62 \\
0.082 \\
P=0.000<0.05\end{array}$ & $\begin{array}{l}\text { Kurang fit } \\
\text { Good fit }\end{array}$ \\
\hline ECVI & $\begin{array}{l}\mathrm{ECVI}<\mathrm{ECVI} \text { for Saturated dan } \\
\text { Independence }\end{array}$ & $\begin{array}{l}\mathrm{M}^{*}=3.43 \\
\mathrm{~S}^{*}=3.44\end{array}$ & Good Fit \\
\hline
\end{tabular}




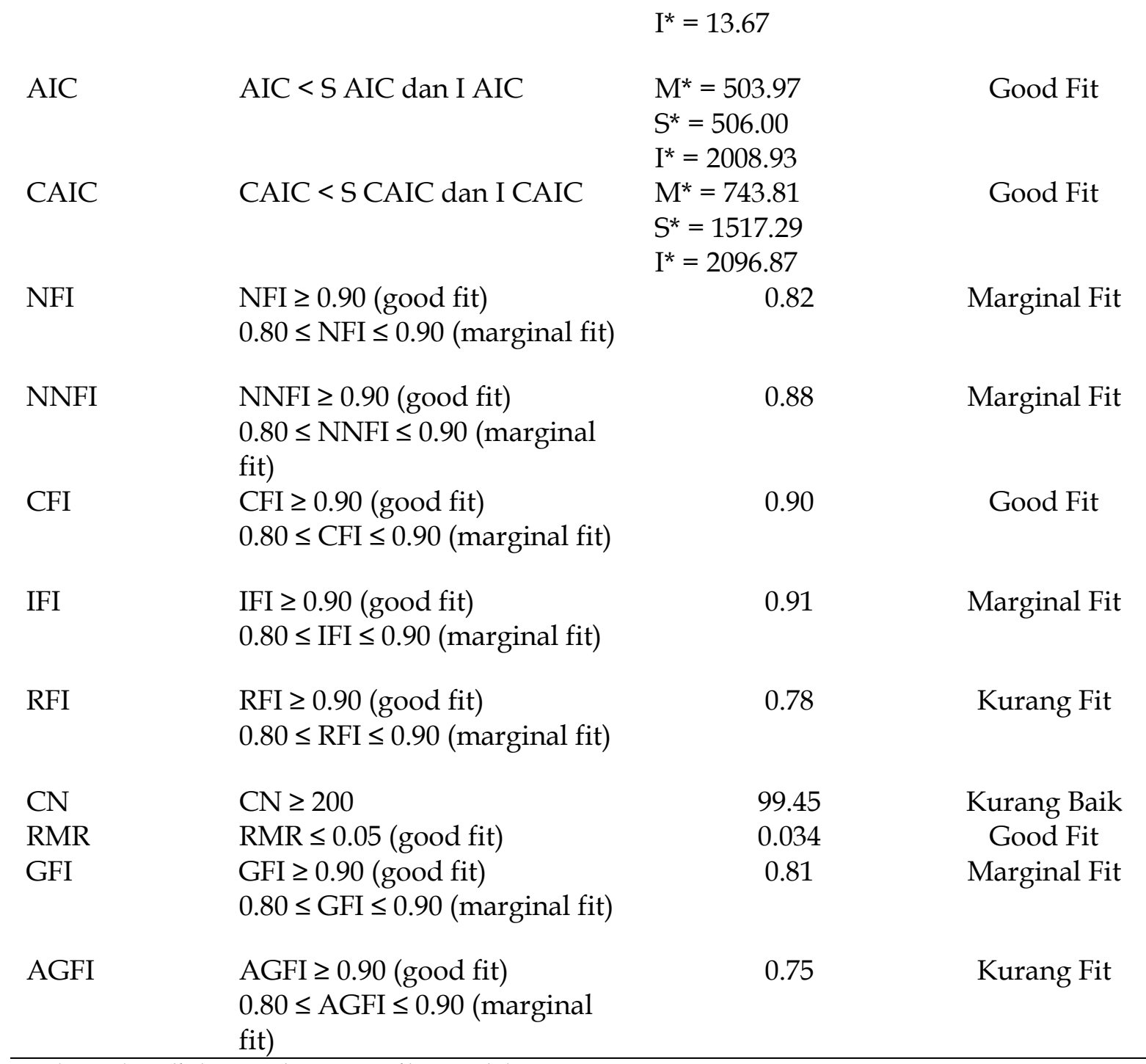

Sumber: Ghozali dan Fuad, 2008; Hasil Pengolahan Data, 2017

Keterangan:

${ }^{*} \mathrm{M}, \mathrm{S}, \mathrm{I}=$ Model, Saturated, Independence

Berdasarkan hasil uji keseluruhan model di atas, 5 dari 15 ukuran kecocokan model memberikan hasil yang kurang baik. Sehingga dapat disimpulkan bahwa model yang dihipotesiskan masih belum cukup baik.

\section{Uji Kecocokan Model Pengukuran}

Setelah uji kecocokan model dan data secara keseluruhan, langkah berikutnya adalah uji kecocokan model pengukuran. Pengujian dilakukan tehadap setiap konstruk atau model pengukuran dengan uji validitas dan reliabilitas dari model pengukuran.
Uji validitas untuk model pengukuran dilakukan dengan mengevaluasi nilai statistik uji $\mathrm{t}$ atau $\mathrm{t}$ hitung dari muatan faktornya (loading factor) dan muatan faktor standarnya (standardized factor loading). Suatu variabel dikatakan memiliki validitas yang baik terhadap konstruk atau variabel latennya jika: (Ghozali dan Fuad, 2008).

1. Nilai $t$ hitung muatan faktornya lebih besar dari nilai kritis (atau $\geq 1,96$ untuk tingkat signifikansi 0,05), dan

2. Muatan faktor standarnya $\geq 0,70$ atau $\geq$ 0,50 . 
Tabel 10 berikut ini memberikan nilai estimasi atau taksiran, standar error, dan nilai $t$ dari muatan faktor setiap variabel atau indikator.

Tabel 10

Estimasi Parameter Model Pengukuran

\begin{tabular}{|c|c|c|c|}
\hline & SLF & Error & t-value \\
\hline $\mathrm{X}_{11} \leftarrow$ Pengetahuan & 0,80 & 0,36 & 10,59 \\
\hline $\mathrm{X}_{12} \leftarrow$ Pengetahuan & 0,75 & 0,43 & 9,83 \\
\hline $\mathrm{X}_{13} \leftarrow$ Pengetahuan & 0,77 & 0,41 & 10,07 \\
\hline $\mathrm{X}_{21} \leftarrow$ Sikap & 0,58 & 0,67 & 7,09 \\
\hline $\mathrm{X}_{22} \leftarrow$ Sikap & 0,84 & 0,29 & 11,44 \\
\hline $\mathrm{X}_{23} \leftarrow$ Sikap & 0,81 & 0,35 & 10,84 \\
\hline $\mathrm{X}_{31} \leftarrow$ Norma & 0,74 & 0,45 & 9,53 \\
\hline Subjektif & & & \\
\hline $\mathrm{X}_{32} \leftarrow$ Norma & 0,67 & 0,55 & 8,35 \\
\hline Subjektif & & & \\
\hline $\mathrm{X}_{33} \leftarrow$ Norma & 0,77 & 0,41 & 9,99 \\
\hline Subjektif & & & \\
\hline $\begin{array}{l}\mathrm{X}_{41} \leftarrow \text { Kendali } \\
\text { Perilaku }\end{array}$ & 0,88 & 0,23 & 11,91 \\
\hline $\begin{array}{l}\mathrm{X}_{42 \leftarrow \text { Kendali }} \\
\text { Perilaku }\end{array}$ & 0,68 & 0,54 & 8,74 \\
\hline $\begin{array}{l}X_{51 \leftarrow \text { Komitmen }} \\
\text { Beragama }\end{array}$ & 0,72 & 0,48 & 9,80 \\
\hline $\begin{array}{l}X_{52 \leftarrow \text { Komitmen }} \\
\text { Beragama }\end{array}$ & 0,73 & 0,47 & 9,90 \\
\hline $\begin{array}{l}X_{53} \leftarrow \text { Komitmen } \\
\text { Beragama }\end{array}$ & 0,81 & 0,35 & 11,49 \\
\hline $\begin{array}{l}X_{54 \leftarrow \text { Komitmen }} \\
\text { Beragama }\end{array}$ & 0,83 & 0,31 & 11,95 \\
\hline $\begin{array}{l}X_{55} \leftarrow \text { Komitmen } \\
\text { Beragama }\end{array}$ & 0,71 & 0,49 & 9,60 \\
\hline $\mathrm{Z}_{1} \leftarrow$ Intensi & 0,70 & 0,51 & \\
\hline $\mathrm{Z}_{2} \leftarrow$ Intensi & 0,82 & 0,33 & 9,27 \\
\hline $\mathrm{Z}_{3} \leftarrow$ Intensi & 0,77 & 0,41 & 8,76 \\
\hline $\mathrm{Y}_{1} \leftarrow$ Perilaku & 0,63 & 0,60 & \\
\hline $\mathrm{Y}_{2} \leftarrow$ Perilaku & 0,86 & 0,26 & 8,13 \\
\hline $\mathrm{Y}_{3} \leftarrow$ Perilaku & 0,67 & 0,56 & 6,80 \\
\hline
\end{tabular}

Sumber: Hasil pengolahan data dengan LISREL 8.5,2017

Untuk uji reliabilitas model pengukuran, dilakukan dengan menggunakan ukuran reliabilitas konstruk (Construct Reliability/CR) dan ukuran ekstrak varian (variant extract/NE).

Pada tabel 10 di atas, menunjukkan semua indikator variabel laten memiliki nilai Standard Loading Factor (SLF) $\geq 0,50$, dan semua variabel latent memiliki nilai tvalue $\geq 1,96$. Hasil ini juga menunjukkan bahwa semua indikator dalam penelitian ini merefleksikan variabel penelitian secara signifikan. Dari hasil estimasi yang diberikan pada tabel 10, dapat dihitung nilai CR dan VE dari setiap variabel laten yang hasilnya diberikan pada tabel 11 berikut: 
Tabel 11

Reliabilitas Model Pengukuran

\begin{tabular}{lrcc}
\hline \multicolumn{1}{c}{ Variabel } & \multicolumn{2}{c}{ Reliabilitas } & Keterangan \\
& $\mathbf{C R} \geq \mathbf{0 , 7 0}$ & VE $\geq \mathbf{0 , 5 0}$ & \\
\hline Pengetahuan & 0,82 & 0,69 & Reliabilitas Baik \\
Sikap & 0,79 & 0,56 & Reliabilitas Baik \\
Norma Subjektif & 0,77 & 0,53 & Reliabilitas Baik \\
Kendali Perilaku & 0,76 & 0,62 & Reliabilitas Baik \\
Komitmen Beragama & 0,87 & 0,58 & Reliabilitas Baik \\
Intensi & 0,81 & 0,58 & Reliabilitas Baik \\
Perilaku & 0,77 & 0,53 & Reliabilitas Baik \\
\hline
\end{tabular}

Sumber: Hasil Pengolahan Data, 2016

Tabel 11 yang merupakan nilai reliabilitas model pengukuran dilihat dari nilai $\mathrm{CR}$ dan VE, menunjukkan bahwa semua model pengukuran dalam penelitian ini adalah reliable atau andal untuk mengukur pengetahuan, sikap, norma subjektif, kendali perilaku, komitmen beragama, intensi, dan perilaku. Hal ini terlihat dari nilai $C R$ dan VE variabel penelitian yang ada, bahwa semua variabel memiliki nilai $C R>0,70$ dan nilai $\mathrm{VE}>0,50$, sehingga model pengukuran dalam penelitian ini andal untuk mengukur variabel pengetahuan, sikap, norma subjektif, kendali perilaku, komitmen beragama, intensi dan perilaku

\section{Analisis Model Struktural}

Pada tahap ini akan dilakukan evaluasi terhadap koefisien-koefisien atau parameter-parameter yang menunjukkan hubungan kausalitas atau pengaruh antara satu konstruk terhadap konstruk lainnya. Evaluasi terhadap model structural juga dapat dikatakan sebagai evaluasi atau pengujian hipotesis yang telah diungkapkan sebelumnya. Hubungan kausalitas antar konstruk dapat dikatakan signifikan secara statistic pada level $\alpha=0,05$ jika nilai $t$ uji $\geq 1,96$ (nilai kritis atau $t$ tabel). Tabel 12 berikut ini memberikan nilai estimasi standar atau nilai koefisien persamaan struktural dan nilai-t dari setiap parameter ditambah dengan kesimpulan signifikansi hubungan kausalitas yang telah dihipotesiskan.

Tabel 12

Evaluasi Terhadap Koefisien Model Struktural

\begin{tabular}{clcc}
\hline \hline Hipotesis & \multicolumn{1}{c}{ Hubungan } & Estimasi Standar & Nilai - t \\
\hline 1 & Pengetahuan $\rightarrow$ Intensi & 0,00 & $0,02^{*}$ \\
2 & Sikap $\rightarrow$ Intensi & $-0,03$ & $-0,34^{*}$ \\
3 & Norma Subjektif $\rightarrow$ Intensi & $-0,05$ & $-0,43^{*}$ \\
4 & Kendali Perilaku $\rightarrow$ Intensi & 0,56 & 4,51 \\
5 & Komitmen Beragama $\rightarrow$ Intensi & 0,51 & 4,69 \\
6 & Intensi $\rightarrow$ Perilaku & 0,95 & 6,89 \\
\hline
\end{tabular}

Keterangan: * Koefisien tidak signifikan pada $\alpha=0,05$

Sumber: Hasil Pengolahan Data, 2016

Berdasarkan evaluasi koefisien model structural pada tabel 12, dapat dilihat bahwa terdapat 3 koefisien yang tidak signifikan secara statistik. Ketiga koefisien itu adalah koefisien yang menggambarkan hubungan antara variabel Pengetahuan terhadap Intensi, variabel Sikap terhadap Intensi, dan variabel Norma Subjektif ter- 
hadap Intensi. Sehingga, dapat disimpulkan bahwa tidak terdapat hubungan kausalitas antara faktor-faktor tersebut seperti yang telah dihipotesiskan. Dengan demikian path atau hubungan antar faktor-faktor tersebut harus dihapus dari model jika ingin memperoleh model yang lebih baik.

\section{Respesifikasi Model}

Untuk memperbaiki kecocokan model terhadap data, maka perlu dilakukan respesifikasi model. Respesifikasi model dapat dilakukan dengan memanfaatkan informasi pada indeks modifikasi yang diberikan pada output. Modification Indices, memberikan dua saran yang dapat dilakukan, yaitu (1) menambah jalur (path) atau hubungan di antara dua variabel latent dan (2) menambah kovariasi antara dua kesalahan (error). Penambahan sebuah lintasan akan menambah hubungan kausal dalam model. Untuk melakukan ini, perlu dukungan teori yang cukup kuat. Pilihan kedua dapat dilakukan dengan beberapa ketentuan berikut: (a) tidak menambahkan kovariasi antara $\delta, \varepsilon$, dan $\zeta$, (b) tambahkan kovariasi di antara dua kesalahan yang didukung oleh alasan atau teori yang kuat, (c) pilih penambahan kovariasi yang menurunkan chi-square terbesar dan sebaiknya model pengukuran dari konstruk atau variabel laten yang sama.

Meskipun demikian, penambahan kovariasi antara $\delta$ dengan $\delta, \varepsilon$ dengan $\varepsilon$, dan $\zeta$ dengan $\zeta$ boleh dilakukan (Wijanto, 2008). Respesifikasi pada model dugaan awal dapat dilakukan berkali-kali sampai didapatkan model terbaik yang dapat merepresentasikan data. Respesifikasi dimulai dengan melepaskan covariance antar indikator yang ditawarkan dalam program LISREL. Model yang telah direspesifikasi menunjukkan perbaikan yang signifikan pada statistic Goodness of Fit (GOF). Sementara untuk membandingkan nilai GOF antar model dapat dilihat pada tabel 13 berikut.

Tabel 13

Perbandingan GOF Statistik

\begin{tabular}{|c|c|c|}
\hline Ukuran GOF & $\begin{array}{c}\text { Hasil Estimasi Model } \\
\text { Awal }\end{array}$ & $\begin{array}{c}\text { Hasil Estimasi Model Setelah } \\
\text { Respesifikasi }\end{array}$ \\
\hline Chi-Square & $\chi^{2}=383.97 ; \mathrm{df}=193$ & $X^{2}=239.22 ; \mathrm{df}=179$ \\
\hline P-value & $\mathrm{p}=0,00<0,05$ & $\mathrm{p}=0.00177<0,05$ \\
\hline Normed Chi-Square & $383.97 / 193=1.99$ & $239.22 / 179=1.34$ \\
\hline GFI & $\mathrm{GFI}=0.81<0.9$ & 0.87 \\
\hline AGFI & AGFI $=0.75<0.9$ & 0.82 \\
\hline PGFI & PGFI $=0.62=0.6$ & 0.62 \\
\hline RMSEA & $0.082>0,08$ & 0.048 \\
\hline $\mathrm{P}$ (close fit) & $P=0.000<0.05$ & $P=0.58$ \\
\hline \multirow[t]{3}{*}{ ECVI } & $\mathrm{M}^{*}=3.43$ & $M^{*}=2.63$ \\
\hline & $S^{*}=3.44$ & $S^{*}=3.44$ \\
\hline & $I^{*}=13.67$ & $I^{*}=13.67$ \\
\hline \multirow[t]{3}{*}{ AIC } & $M^{*}=503.97$ & $M^{*}=387.22$ \\
\hline & $S^{*}=506.00$ & $S^{*}=506.00$ \\
\hline & $I^{*}=2008.93$ & $I^{*}=2008.93$ \\
\hline \multirow[t]{3}{*}{ CAIC } & $\mathrm{M}^{*}=743.81$ & $M^{*}=683.02$ \\
\hline & $S^{*}=1517.29$ & $S^{*}=1517.29$ \\
\hline & $I^{*}=2096.87$ & $I^{*}=2096.87$ \\
\hline NFI & 0.82 & 0.88 \\
\hline
\end{tabular}


266 Ekuitas: Jurnal Ekonomi dan Keuangan - Volume 2, Nomor 2, Juni 2018 : 247 - 270

\begin{tabular}{lcc} 
NNFI & 0.88 & 0.95 \\
CFI & 0.90 & 0.96 \\
IFI & 0.91 & 0.97 \\
RFI & 0.78 & 0.84 \\
CN & 99.45 & 138.89 \\
RMR & 0.034 & 0.029 \\
\hline
\end{tabular}

Sumber: Hasil Pengolahan Data, 2017

Dari perbandingan uji keseluruhan model dugaan awal dengan model hasil respesifikasi di atas, dapat disimpulkan bahwa model respesifikasi jauh lebih baik daripada model dugaan awal.
Selanjutnya dapat dihitung validitas dan reliabilitas model pengukuran setelah model dimodifikasi dan hasilnya ditunjukkan pada tabel 14

Tabel 14

Reliabilitas Model Respesifikasi

\begin{tabular}{|c|c|c|c|c|c|}
\hline & \multirow{2}{*}{$\begin{array}{c}\text { SLF } \\
\text { Awal }\end{array}$} & \multirow{2}{*}{$\begin{array}{l}\text { SLF Setelah } \\
\text { Respesifikasi } \\
\text { Model }\end{array}$} & \multirow[t]{2}{*}{ Error } & \multicolumn{2}{|c|}{ Reliabilitas } \\
\hline & & & & $C R \geq 0,70$ & $V E \geq 0,50$ \\
\hline Pengetahuan & & & & 0,82 & 0,60 \\
\hline $\mathrm{X}_{11}$ & 0,80 & 0,80 & 0,36 & & \\
\hline$X_{12}$ & 0,75 & 0,76 & 0,43 & & \\
\hline $\mathrm{X}_{13}$ & 0,77 & 0,77 & 0,41 & & \\
\hline Sikap & & & & 0,68 & 0,42 \\
\hline$X_{21}$ & 0,58 & 0,69 & 0,52 & & \\
\hline$X_{22}$ & 0,84 & 0,65 & 0,58 & & \\
\hline$X_{23}$ & 0,81 & 0,60 & 0,64 & & \\
\hline Norma & & & & 0,76 & 0,52 \\
\hline Subjektif & & & & & \\
\hline$X_{31}$ & 0,74 & 0,72 & 0,48 & & \\
\hline$X_{32}$ & 0,67 & 0,67 & 0,56 & & \\
\hline $\mathrm{X}_{33}$ & 0,77 & 0,77 & 0,41 & & \\
\hline Kendali & & & & 0.76 & 0.62 \\
\hline Perilaku & & & & & \\
\hline$X_{41}$ & 0,88 & 0,89 & 0,21 & & \\
\hline $\mathrm{X}_{42}$ & 0,68 & 0,67 & 0,55 & & \\
\hline Komitmen & & & & 0,87 & 0,57 \\
\hline Beragama & & & & & \\
\hline$X_{51}$ & 0,72 & 0,72 & 0,48 & & \\
\hline$X_{52}$ & 0,73 & 0,73 & 0,47 & & \\
\hline$X_{53}$ & 0,81 & 0,81 & 0,35 & & \\
\hline$X_{54}$ & 0,83 & 0,82 & 0,33 & & \\
\hline$X_{55}$ & 0,71 & 0,71 & 0,50 & & \\
\hline Intensi & & & & 0,77 & 0,53 \\
\hline $\mathrm{Z}_{1}$ & 0,70 & 0,70 & 0,51 & & \\
\hline $\mathrm{Z}_{2}$ & 0,82 & 0,75 & 0,43 & & \\
\hline $\mathrm{Z}_{3}$ & 0,77 & 0,73 & 0,46 & & \\
\hline Perilaku & & & & 0,76 & 0,52 \\
\hline
\end{tabular}




\begin{tabular}{cccc}
$\mathrm{Y}_{1}$ & 0,63 & 0,64 & 0,59 \\
$\mathrm{Y}_{2}$ & 0,86 & 0,85 & 0,28 \\
$\mathrm{Y}_{3}$ & 0,67 & 0,67 & 0,56 \\
\hline
\end{tabular}

Sumber: Hasil Pengolahan Data, 2017

Pada tabel 14 di atas, menunjukkan bahwa semua indikator variabel laten memiliki nilai Standard Loading Factor (SLF) $\geq 0,50$ dan nilai $\mathrm{t}$-value $\geq 1,96$. Nilai SLF setiap indikator tersebut ada sebagian yang mengalami peningkatan setelah dilakukan modifikasi pada model pengukuran dan structural. Tabel 14 juga menunjukkan nilai reliabilitas model pengukuran dilihat dari nilai CR dan VE. Nilai CR dan VE yang ada pada tabel 14 menunjukkan bahwa model dalam penelitian ini adalah reliable atau andal untuk mengukur pengetahaun, norma subjektif, kendali perilaku, komitmen beragama, intensi, dan perilaku. Sementara untuk mengukur sikap, model pengukuran dalam penelitian ini kurang andal.

Setelah mendapatkan validitas dan reliabilitas model pengukuran, maka tahap berikutnya evaluasi terhadap koefisien model struktural. Evaluasi terhadap koefisien model struktural disajikan pada tabel 15 berikut:

Tabel 15

Evaluasi Terhadap Koefisien Model Struktural

\begin{tabular}{|c|c|c|c|c|}
\hline Hipotesis & Hubungan & $\begin{array}{c}\text { Total } \\
\text { Estimasi } \\
\text { Standar }\end{array}$ & $\begin{array}{c}\text { Nilai-t } \\
\text { Langsung } \\
X \\
\text { terhadap } \\
\text { Z }\end{array}$ & $\begin{array}{c}\text { Nilai-t } \\
\text { langsung } \\
Z \\
\text { terhadap } \\
Y\end{array}$ \\
\hline 1 & Pengetahuan $\rightarrow$ Intensi $\rightarrow$ Perilaku & $\begin{array}{c}0,02 * 0,99= \\
0,0198\end{array}$ & $0,18^{*}$ & 7,14 \\
\hline 2 & Sikap $\rightarrow$ Intensi $\rightarrow$ Perilaku & $\begin{array}{c}-0,18^{*} 0,99= \\
-0,1782\end{array}$ & $-0,54^{*}$ & 7,14 \\
\hline 3 & $\begin{array}{l}\text { Norma } \\
\text { Subjektif } \rightarrow \text { Intensi } \rightarrow \text { Perilaku }\end{array}$ & $\begin{array}{c}0,11^{*} 0,99= \\
0,1089\end{array}$ & $0,56^{*}$ & 7,14 \\
\hline 4 & $\begin{array}{l}\text { Kendali } \\
\text { Perilaku } \rightarrow \text { Intensi } \rightarrow \text { Perilaku }\end{array}$ & $\begin{array}{c}0,52 * 0,99= \\
0,5148\end{array}$ & 4,12 & 7,14 \\
\hline 5 & $\begin{array}{l}\text { Komitmen } \\
\text { Beragama } \rightarrow \text { Intensi } \rightarrow \text { Perilaku }\end{array}$ & $\begin{array}{c}0,59 * 0,99= \\
0,5841\end{array}$ & 4,46 & 7,14 \\
\hline
\end{tabular}

Keterangan: ${ }^{*}$ Koefisien tidak signifikan pada $\alpha=0,05$

Sumber: Hasil Pengolahan Data, 2017.

Tabel 14 merupakan jawaban dari hipotesis yang disampaikan di awal penulisan artikel ini. Hipotesis pertama berkaitan dengan adanya pengaruh yang signifikan tingkat pengetahuan terhadap perilaku melalui variabel intensi. Hasil pengolahan data menunjukkan bahwa Variabel Pengetahuan memiliki pengaruh yang signifikan terhadap perilaku melalui intensi untuk mengkonsumsi produk halal. Koefisien pengaruh yang tidak secara langsung tersebut adalah sebesar 0,0198. Angka koefisien ini termasuk nilai yang kecil dibandingkan dengan variabel lain, hal ini salah satunya disebabkan karena secara langsung, variabel Pengetahuan konsumen mengenai produk halal tidak signifikan terhadap intensi masyarakat mengkonsumsi produk halal. Sementara, variabel Intensi memiliki pengaruh yang signifikan terhadap perilaku konsumsi produk halal dengan nilai $\mathrm{t}$ sebesar 7,14 dan koefisien 
pengaruh Intensi terhadap Perilaku sebesar 0,99 , sebuah nilai koefisien yang besar.

Variabel Sikap dan Norma Subjektif memiliki hasil yang sama. Pengaruh yang terbentuk variabel Sikap dan Norma Subjektif terhadap Variabel Perilaku adalah pengaruh secara tidak langsung melalui variabel Intensi. Koefisien Variabel Sikap terhadap Variabel Perilaku melalui Variabel Intensi adalah sebesar 0,1782 dan memiliki pengaruh yang negatif. Pengaruh yang negatif ini adalah pengaruh langsung variabel Sikap terhadap Variabel Intensi, dan pengaruh langsung tersebut bukanlah pengaruh yang signifikan. Sehingga, nilai koefisien yang terbentuk juga bernilai rendah dibandingkan dengan pengaruh variabel lain.

Variabel Norma Subjektif memiliki pengaruh yang positif secara langsung terhadap Intensi, namun tidak signifikan. Sementara Variabel Norma Subjektif memiliki pengaruh yang positif dan signifikan terhadap Variabel Perilaku melalui Variabel Intensi untuk mengkonsumsi produk halal.

Variabel Kendali Perilaku memiliki pengaruh yang positif dan signifikan terhadap variabel Perilaku melalui variabel Intensi. Total koefisien pengaruh variabel kendali perilaku ini terhadap variabel perilaku adalah sebesar 0,5148. Nilai koefisien yang terbentuk cukup besar, hal ini salah satu penyebabnya karena variabel kendali perilaku juga memiliki pengaruh yang positif dan signifikan secara langsung terhadap variabel Intensi.

Variabel Komitmen Beragama juga menunjukkan hasil yang sama. Bahwa makin besar komitmen seseorang terhadap pelaksanaan ajaran agama dalam mengkonsumsi produk halal, maka makin besar intensi dan perilaku seseorang positif untuk selalu mengkonsumsi produk halal.

\section{SIMPULAN DAN SARAN}

Berdasarkan hasil penelitian dan pembahasan yang sudah diuraikan, dapat disimpulkan bahwa; Pertama, variabel Pengetahuan memiliki pengaruh yang signifikan terhadap perilaku melalui intensi untuk mengkonsumsi produk halal. Kedua, Pengaruh yang terbentuk variabel Sikap dan Norma Subjektif terhadap Variabel Perilaku adalah pengaruh secara tidak langsung melalui variabel Intensi. Ketiga, Variabel Kendali Perilaku memiliki pengaruh yang positif dan signifikan terhadap variabel Perilaku melalui variabel Intensi. Keempat, Variabel Komitmen Beragama juga menunjukkan hasil yang sama. Bahwa makin besar komitmen seseorang terhadap pelaksanaan ajaran agama dalam mengkonsumsi produk halal, maka makin besar intensi dan perilaku seseorang positif untuk selalu mengkonsumsi produk halal.

Dengan hasil penelitian yang diperoleh, disarankan bahwa; Pertama, perlu penyadaran mengkonsumsi produk halal dengan meningkatkan komitmen beragama seseorang. Hasil penelitian menunjukkan bahwa Variabel Komitmen Beragama memiliki pengaruh yang besar dalam perilaku mengkonsumsi produk halal. Kedua, perlu ditingkatkan peran masyarakat baik dari internal maupun eksternal dalam mengendalikan perilaku seseorang untuk mengkonsumsi produk halal. Hal ini terlihat dari peran kendali perilaku yang memiliki pengaruh yang cukup besar dalam perilaku seseorang untuk mengkonsumsi produk halal.

\section{DAFTAR PUSTAKA}

Abhimantra, A., A. R. Maulina., E. Agustianingsih. 2013. Analisis FaktorFaktor yang Mempengaruhi Nasabah (Mahasiswa) dalam Memilih Menabung pada Bank Syariah. Proceeding PESAT (Psikologi, Ekonomi, Sastra, Arsitektur $\mathcal{E}$ Teknik Sipil) 5(2013): 170-177.

Abidin, Z. 2012. Rahasia Hukum Islam Dalam Ruang Peribadatan. Jurnal Adabiyah 12(2).

Aisyah, M. 2014. The Influence of Religious Behavior on Consumers' Intention to Purchase Halal-Labeled Products. Business and Entrepreneurial Review 14(1): 1532. 
Alam, S. S. dan M. S. Nazura. 2011. Applying the Theory of Planned Behavior (TPB) in Halal Food Purchasing. International Journal of Commerce and Management 21(1): 8-20.

Arief, S. 2012. Konsumen Rasional dalam Perspektif Islam. Islamic Economics Journal 1(1): 17-30.

Astogini, D., Wahyudin, S. Z. Wulandari. 2011. Aspek Religiusitas dalam Keputusan Pembelian Produk Halal (Studi tentang Labelisasi Halal pada Produk Makanan dan Minuman Kemasan). JEBA 13(1): 1-8.

Bentler, P. M. 2010. SEM with Simplicity and Accuracy. Journal of Consumer Psychology 20(2): 215-220.

Bonne, K., I. Vermeir, F. Bergeaud-Blackler, dan W. Verbeke. 2007. Determinants of Halal Meat Consumption in France. British Food Journal 109(5): 367-386.

Borzooei, M. dan M. Asgari. 2013. The Halal Brand Personality and Its Effect on Purchase Intention. Interdisciplinary Journal of Contemporary Research in Business 5(3): 481-491.

Endah, N. H. 2014. Perilaku Pembelian Kosmetik Berlabel Halal oleh Konsumen Indonesia. Jurnal Ekonomi dan Pembangunan 22(1): 11-25.

Ghani, F. B. A., S. L. B. A. Kamal., A. B. A. Aziz. 2014. The Implication of Parenting Styles on the Akhlak of Muslim Teenagers in the South of Malaysia. Procedia - Social and Behavioral Sciences 114(2014): 761-765.

Ghozali, I. dan Fuad. 2008. Structural Equation Modeling: Teori, Konsep, dan Aplikasi dengan Program Lisrel 8.80. Badan Penerbit Universitas Diponegoro. Semarang.

Ghufron, N. dan R. S. Risnawita. 2010. Teoriteori Psikologi. Ar - Ruzz Media. Jakarta.

Hakim, L. 2012. Internalisasi Nilai-Nilai Agama Islam dalam Pembentukan Sikap dan Perilaku Siswa Sekolah Dasar Islam Terpadu Al-Muttaqin Kota Tasikmalaya. Jurnal Pendidikan Agama Islam Ta'lim 10(1): 67-77.
Herlyana, E. 2012. Fenomena Coffee Shop Sebagai Gejala Gaya Hidup Baru Kaum Muda. ThaqÃfiyyÃT 13(1): 187-204.

Huda, N., N. Rini, Y. Mardoni, P. Putra. 2012. The Analysis of Attitudes, Subjective Norms, and Behavioral Control on Muzakki's Intention to Pay Zakah. International Journal of Business and Social Science 3(22): 271-279.

Jusmaliani dan H. Nasution. 2009. Religiosity Aspect in Consumer Behaviour: Determinants of Halal Meat Consumption. Asean Marketing Journal I(1): 1-12.

Kamal, S. S. L. A. dan F. A. Ghani. 2014. Emotional Intelligence and Akhlak among Muslim Adolescents in One of the Islamic Schools in Johor, South Malaysia. Procedia - Social and Behavioral Sciences 114(2014): 687-692.

Khalek, A. A. dan S. H. S. Ismail. 2015. Why are We Eating Halal - Using the Theory of Planned Behavior in Predicting Halal Food Consumption among Generation $\mathrm{Y}$ in Malaysia. International Journal of Social Science and Humanity 5(7): 608612.

Kotler, P. dan K. L. Keller. 2009. Manajemen Pemasaran. Jilid Satu. Edisi Ketiga Belas. Penerbit Erlangga. Jakarta.

Lada, S., G. Harvey, dan Amin. 2009. Predicting Intention to Choose Halal Products Using Theory of Reasoned Action. International Journal of Islamic and Middle Eastern Finance and Management 2(1): 66-67.

Marreiros, C. dan M. Ness. 2009. A Conceptual Framework of Consumer Food Choice Behaviour. CEFAGE-UE Working Paper 2009(6): 1-25.

Mathras, D., A. B. Cohen, N. Mandel, D. G. Mick. 2016. The Effects of Religion on Consumer Behavior: A Conceptual Framework and Research Agenda. Journal of Consumer Psychology 26: 298311.

Mokhlis, S. 2009. Relevancy and Measurement of Religiosity in Consumer Behavior Research. International Business Research 2(3):75-84. 
Monintja, T. C. N. 2015. Hubungan antara Karakteristik Individu, Pengetahuan dan Sikap dengan Tindakan PSN DBD Masyarakat Kelurahan Malalayang I Kecamatan Malalayang Kota Manado. JIKMU 5(2b): 503-519.

Notoatmodjo, S. 2010. Konsep Perilaku Kesehatan. Promosi Kesehatan Teori dan Aplikasi. Edisi Revisi 2010. Rineka Cipta. Jakarta.

Pusat Pengkajian dan Pengembangan Ekonomi Islam. 2008. Ekonomi Islam. PT Raja Grafindo Persada. Jakarta.

Putriani, Y. H. dan A. Shofawati. 2015. Pola Perilaku Konsumsi Islami Mahasiswa Muslim Fakultas Ekonomi dan Bisnis Universitas Airlangga Ditinjau dari Tingkat Religiusitas. JESTT 2(7): 570582.

Reuters, T. 2014. State of Global Economy Report and Indicator 2014/2015. https://halalfocus.net/state-of-global-islamic -economy-report-indicator-20142015/.

Diakses pada 25 April 2017.

Salehudin, I. dan Lutfhi. 2011. Marketing Impact of Halal Labeling toward Indonesian Muslim Consumer's Behavioral Intention. ASEAN Marketing Journal 3(1): 35-44.

Santoso, A. dan Indarini. 2010. Studi Deskriptif tentang Perbedaan Behavioral Intention antara Produk Minuman Pocari Sweat dan Mizone di Surabaya: Pendekatan Fishbein's Behavioral Intention Model. Proceedings The 7th Ubaya International Annual Symposium on Management.

Schiffman, L. G. dan L. L. Kanuk. 2009. Consumer Behavior. 10th Edition. Prentice Hall Inc, Upper Saddle River. New Jersey.
Shafie, S. dan N. M. Othman. 2008. Halal Certification: an International Marketing Issues and Challenges. http://www. ctwcongress.de/ifsam/download/track_13/pa p00226.pdf. Diakses pada 14 April 2017.

Shook, C. dan C. Bratianu. 2010. Entrepreneurial Intent in a Transitional Economy: an Application of the Theory of Planned Behavior to Romanian Students. International Entrepreneurship and Management Journal 6: 231-247.

Soesilowati, E. S. 2010. Business Opportunity for Halal Products in Global Market: Moslem Consumer Behavior and Halal Food Consumption. Journal of Indonesian Social Science and Humanities 3: 151-160.

Sutrisno, R. 2013. Perilaku Konsumen Muslim: Persepsi Religiusitas dan Persepsi Atribut Produk terhadap Loyalitas Produk Makanan dan Minuman Berlabel Halal di Kalangan Mahasiswa Muslim di Bandung. Sigma-Mu 5(2): 1836.

Wigati, S. 2011. Perilaku Konsumen Dalam Perspektif Ekonomi Islam. Maliyah 1(1): 22-39.

Wijanto, S. H. 2008. Structural Equation Modelling dengan Lisrel 8.8 Konsep dan Tutorial. Graha Ilmu. Yogyakarta.

Yusoff, S. Z. H., N. A. Adzharuddin, J. Bolong. 2014. Faktor Pencetus Perilaku Pencarian Maklumat Produk Halal dalam Kalangan Keluarga Islam. Global Media Journal 3(2): 69-82.

Zuhdi, B. Suharjo, dan H. Sumarno. 2016. Perbandingan Pendugaan Parameter Koefisien Struktural Model melalui SEM dan PLS-SEM. Jurnal Matematika dan Aplikasinya 15(2): 11-22. 